\title{
Faktor Terkait Inisiasi Menyusu Dini pada Ibu Postpartum di Rumah Sakit Umum Daerah Kota Cilegon
}

\author{
Factors Related to Early Initiation of Breastfeeding among Postpartum \\ Mother in Regional Public Hospital in Cilegon City
}

\author{
Mulia Lestari ${ }^{1}$ \\ 1) Kelompok Studi Mutu Layanan Kesehatan, Fakultas Kesehatan Masyarakat, Universitas Indonesia, Depok, 16424, \\ Indonesia \\ Korespondensi: mulialestari8@gmail.com
}

Submitted: 8 Februari 2019, Revised: 5 April 2019, Accepted: 18 April 2019

https://doi.org/10.22435/jpppk.v3i1.1228

\begin{abstract}
Abstrak
Inisiasi Menyusu Dini (IMD) merupakan kesempatan bayi yang dilahirkan dalam 24 bulan terakhir dapat menyusu secara alami dengan meletakkannya di perut ibunya selama satu jam setelah kelahiran. Kegiatan ini bertujuan meningkatkan jalinan kasih sayang ibu dan bayi, mempertahankan suhu bayi tetap hangat, merangsang kontraksi otot rahim sehingga mengurangi risiko perdarahan sesudah melahirkan dan memperbesar peluang ibu untuk memantapkan dan melanjutkan kegiatan menyusui selama masa bayi (6 bulan-2 tahun). Tujuan penelitian ini adalah untuk mengetahui pelaksanaan dan faktor terkait IMD di Rumah Sakit Umum Daerah (RSUD) Kota Cilegon. Jenis penelitian bersifat deskriptif dengan menggunakan metode penelitian kualitatif. Wawancara mendalam dilakukan terhadap 14 informan dan metode observasi pelaksanaan persalinan spontan di ruang bersalin. Hasil penelitian menunjukkan bahwa pelaksanaan IMD di RSUD Kota Cilegon ditinjau dari struktur, proses dan output terlaksana cukup baik pada persalinan spontan dan belum terlaksana pada persalinan post-sectio caesaria. Penyebab pelaksanaan IMD belum optimal karena prosedur operasional baku IMD yang dimiliki rumah sakit belum diterapkan pada semua jenis metode persalinan. IMD hanya dilaksanakan pada proses persalinan pervaginam. Selain itu, pelatihan tenaga kesehatan belum diberikan secara menyeluruh. Saran yang dapat dilakukan adalah perbaikan prosedur operasional baku IMD dan inhouse training di rumah sakit tentang IMD.
\end{abstract}

Kata kunci: Inisiasi Menyusu Dini (IMD), ibu postpartum, rumah sakit

\begin{abstract}
Early initiation of breastfeeding (EIB) is opportunity of babies born in the past 24 months to be able to suckle naturally by placing the baby in the mother's stomach within an hour of birth. This activity aims to improve the affection of mothers and babies, keep the temperature of the baby warm, stimulate uterine muscle contraction, thereby reducing the risk of postpartum bleeding and increase the chances of the mother to establish and continue breastfeeding during infancy (6 months-2 years). The purpose of this study was to find out the implementation of EIB at the Cilegon Hospital and their factors related. This type of research is descriptive by using qualitative research methods. In-depth interviews were carried out on 14 informants and methods of observing the implementation of spontaneous labor in the delivery room. The results showed that the implementation of EIB at the Hospital of Cilegon in terms of structure, process and output was carried out quite well at spontaneous labor and had not been carried out in the post sectio caesaria delivery. The causes of the implementation of EIB have not been optimal because the Standard Operational Procedures (SOP) for EIB owned by hospitals have not been for all types of labor methods, EIB is carried out only in the vaginal delivery process. In addition, the training of health workers has not been given as a whole. Suggestions that can be made is to improve the SOP for EIB and inhouse training at the hospital about EIB.
\end{abstract}

Keywords: Early Initiation of Breastfeeding (EIB), postpartum mother, hospital. 


\section{Pendahuluan}

Pemberian Air Susu Ibu (ASI) saja pada bayi sampai usia enam bulan tanpa tambahan cairan ataupun makanan lain disebut sebagai ASI Eksklusif (WHO). ASI eksklusif dianjurkan oleh United Nation Childrens Fund (UNICEF) dan World Health Organization (WHO) karena ASI tidak terkontaminasi dan mengandung banyak gizi yang diperlukan pada umur tersebut. Pemberian ASI Eksklusif memiliki kontribusi yang besar terhadap tumbuh kembang dan daya tahan tubuh anak. Anak yang diberi ASI Eksklusif akan tumbuh dan berkembang secara optimal dan tidak mudah sakit. Hal tersebut sesuai dengan beberapa kajian dan fakta global. Kajian global "The Lancet Breastfeeding Series, 2016 telah membuktikan bahwa (1) Menyusui Eksklusif menurunkan angka kematian karena infeksi sebanyak $88 \%$ pada bayi berusia kurang dari 3 bulan, 2) Sebanyak 31,36\% dari $37,94 \%$ anak sakit, karena tidak menerima ASI Eksklusif. ASI Eksklusif berkontribusi dalam menurunkan risiko obesitas dan penyakit kronis. ${ }^{1}$ UNICEF dan WHO merekomendasikan sebaiknya anak hanya disusui ASI selama paling sedikit enam bulan. Hal ini bertujuan untuk menurunkan angka kesakitan dan kematian anak. Menurut WHO/ UNICEF, standar emas pemberian makan pada bayi dan anak adalah 1) meneruskan menyusui anak sampai umur 24 bulan atau lebih 2) menyusui bayi secara eksklusif sejak lahir sampai dengan umur 6 bulan, dan 3) mulai umur 6 bulan bayi mendapat Makanan Pendamping ASI (MP-ASI) yang bergizi sesuai dengan kebutuhan tumbuh kembangnya dan 4) mulai segera menyusui dalam satu jam setelah lahir. Kegiatan mulai segera menyusu dalam satu jam setelah lahir atau biasa disebut Inisiasi Menyusu Dini (IMD) merupakan salah satu bentuk dukungan untuk keberhasilan program pemberian ASI. ${ }^{2}$ IMD merupakan proses alamiuntukmenyusu, yaitu dengan memberikan kesempatan pada bayi untuk mencari dan mengisap ASI sendiri, dalam satu jam pertama awal kehidupan dengan meletakan bayi sesegera mungkin di dada ibu setelah lahir. ${ }^{3}$ Pengamatan yang dilakukan oleh beberapa pakar laktasi hampir di seluruh dunia menemukan bahwa jika setiap bayi yang baru dilahirkan dan diletakkan di dada ibunya, dengan melakukan kontak kulit antara ibu dan bayi, maka bayi dengan refleks alaminya akan memiliki kemampuan untuk mencari dan menemukan puting ibunya dan menyusu hingga puas untuk pertama kalinya. ${ }^{4}$ Sesuai dengan Peraturan Pemerintah (PP) nomor 33 tahun 2012 tentang Pemberian ASI Eksklusif, pasal 9 ayat 1 disebutkan bahwa Tenaga Kesehatan dan penyelenggaran fasilitas pelayanan kesehatan wajib melakukan IMD terhadap bayi yang baru dilahirkan kepada ibunya paling singkat selama satu jam. ${ }^{5}$

IMD yang dilakukan oleh tenaga kesehatan di Rumah Sakit Umum Daerah (RSUD) Kota Cilegon sebagai salah bentuk dukungan kepada ibu bersalin untuk bisa menyusui eksklusif. Berdasarkan data pada Bulan Januari - September tahun 2018, RSUD Kota Cilegon memiliki rata-rata 73,9\% bayi yang dilakukan IMD pada persalinan pervaginam. Menurut salah satu informan saat peneliti melakukan studi awal, IMD di RSUD Kota Cilegon Cilegon pelaksanaannya belum terlaksana pada semua persalinan, hanya dilaksanakan pada kasus persalinan pervaginam. IMD merupakan salah satu bagian layanan kesehatan dari Asuhan Persalinan Normal (APN). Menurut Donabedian cara langsung untuk menilai kualitas suatu pelayanan adalah dengan menilai proses pelayanan tersebut, namun ada pendekatan tidak langsung yang menilai keseluruhan aspek pelayanan, yaitu dengan menilai struktur dan hasil/output. ${ }^{6}$

IMD bagi bayi banyak memberikan manfaat di antaranya menurunkan angka kematian bayi karena hipotermi, mendapatkan antibodi dari kolostrum, menelan bakteri aman yang berkoloni di usus menyaingi bakteri patogen, membuat kadar glukosa bayi lebih baik setelah beberapa jam setelah persalinan dan menurunkan intensitas ikterus karena pengeluaran mekonium ang lebih dini. ${ }^{7}$ Sementara manfaat IMD bagi ibu antara lain membuat jalinan kasih sayang ibu dan bayi, ibu merasa lebih tenang, membantu kotraksi uterus, mengurangi risiko perdarahan dan mempercepat pengeluaran plasenta. ${ }^{8}$ Menyadari pentingnya IMD dari dukungan petugas dan pelayanan kesehatan dalam meningkatkan keberhasilan menyusui, peneliti ingin mengetahui pelaksanaan dan faktor terkait IMD di RSUD Kota Cilegon 


\section{Bahan dan Metode}

Penelitian ini menggunakan metode penelitian kualitatif. Lokasi penelitian dilakukan di RSUD Kota Cilegon pada Bulan Desember 2018. Pemilihan informan berdasarkan prinsip kesesuaian (appropiateness) dan kecukupan (adequacy), yaitu berdasarkan pengetahuan dan pengalaman yang dimiliki informan dan memenuhi kategori yang berkaitan dengan topik penelitian sampai tidak ditemukan informasi baru. Informan tersebut adalah satu orang dari manajemen rumah sakit, kepala ruangan bersalin, satu orang dokter spesialis kandungan, tiga orang bidan ruang bersalin, enam orang pasien postpartum normal dan dua orang pasien post sectio caesaria untuk dilakukan wawancara mendalam. Pemilihan informan dalam penelitian menggunakan metode purposive sampling, di mana peneliti menentukan informan yang memiliki kapabilitas dalam menjawab pertanyaan-pertanyaan penelitian.

Pengumpulan data yang digunakan dalam penelitian ini adalah dengan menggunakan pedoman wawancara mendalam, observasi langsung dan telaah dokumen. Data primer diperoleh dari wawancara mendalam dan observasi langsung, sedangkan data sekunder diperoleh dari telaah dokumen. Data yang telah dikumpulkan melalui wawancara mendalam diolah dengan membuat transkrip hasil pembicaraan tersebut. Selanjutnya data tersebut dianalisis dengan metode analisis isi (content analysis), yaitu membandingkan hasil penelitian dengan teori-teori yang ada di kepustakaan.

\section{Hasil}

Berdasarkan hasil observasi yang dilakukan peneliti, pelaksanaan IMD di ruang bersalin. IMD yang dilakukan di ruang bersalin pada persalinan normal dilakukan selama satu jam lebih enam menit. Pelaksanaan IMD pada persalinan pervaginam di ruang bersalin dikatakan cukup baik. Berdasarkan hasil wawancara kepada informan ibu, sebagian besar dilakukan IMD. Dari lima orang informan ibu yang melakukan persalinan normal, satu di antaranya tidak dilakukan IMD karena alasan medis, yaitu kondisi bayi yang tidak baik karena tidak segera menangis.

"Iya pas bayi ini lahir, ditaro di dada."

(Informan ibu 30th, melahirkan normal, IMD)
"Engga. Pas dedenya lahir, langsung dibawa ke ruang bayi. Jadi lahirnya itu ga nangis. Jadi langsung dibawa kesana."

(Informan ibu 28th, melahirkan normal, tidak IMD)

Sementara pelaksanaan IMD di ruang operasi belum bisa diwujudkan. Pelaksanaan IMD di ruang operasi belum bisa dilaksanakan disebabkan sebagian besar kasus persalinan yang terjadi di rumah sakit merupakan kasus dengan kegawatdaruratan dan belum terpenuhinya kehadiran dokter anak di ruang operasi.

"Kalo yang sesar selama ini si belum... ya kayaknya tidak memungkinkan. Terus kan belum ada dokter SpA yang mengawasi disananya."

(Informan Bidan Ruang Bersalin, 33th)

\section{Prosedur Operasional Baku IMD}

Prosedur operasional baku (POB) IMD di RSUD Kota Cilegon sudah ada, hanya saja POB tersebut hanya berlaku untuk persalinan pervaginam. Berdasarkan telaah dokumen $\mathrm{POB}$ IMD terakhir dibuat pada tahun 2016 dan belum dilakukan revisi. Sementara belum terdapatnya $\mathrm{POB}$ pelaksanaan IMD untuk ibu yang melahirkan secara sectio caesaria. Hal ini dikarenakan adanya kondisi yang tidak memungkinkan untuk dilakukan IMD karena sebagian besar merupakan kasus persalinan dengan kegawatdarutan dan kendala pada sumber daya manusia yang belum bisa dipenuhi, yakni pemenuhan kehadiran dokter anak di ruang operasi serta keterlibatan dari tenaga kesehatan lainnya seperti persetujuan dokter operator dan anestesi.

"Yaa itu tadi kan IMD kita masi yang pervaginam aja..."

\section{(Kepala Ruangan Bersalin, 40th)}

\section{Pelatihan Tenaga Kesehatan RS yang berkaitan dengan IMD}

Pelatihan yang berkaitan dengan IMD belum merata dilakukan kepada seluruh tenaga kesehatan di RSUD Kota Cilegon. Dari empat tenaga kesehatan, yakni satu dokter dan tiga bidan. Salah satu di antaranya mengatakan pernah mengikuti pelatihan Asuhan Persalinan Normal (APN). Sementara tiga tenaga kesehatan lainnya mengatakan karena belum memiliki waktu yang sesuai.

"Kalo pelatihan APN sekitar 2015 apa 2016 gitu. 
Yaa antara lima belas atau enam belas gitu.. Nah didalemnya kan ada IMD juga."

(Bidan Ruang Bersalin, 33th)

"Secara khusus si belum, secara pribadi juga belum ...yaa karena belum sempat. Tapi ilmu dan pengetahuan IMD kalo selama pendidikan ya itu ada."

(dr. SpOG, 35th)

\section{Pengetahuan Tenaga Kesehatan tentang IMD}

Berdasarkan hasil wawancara didapatkan bahwa tenaga kesehatan baik bidan dan dokter meski sebagian di antaranya meski belum mendapatkan pelatihan, memiliki pengetahuan yang cukup baik tentang IMD. Informan menjelaskan bahwa IMD dilakukan setelah bayi lahir, dengan waktu satu jam. Selain itu, informan mampu menyampaikan manfaat dari IMD di antaranya mencegah hipotermi, mempertahankan bayi supaya tetap hangat, memperoleh kolostrum yang sangat bermanfaat bagi sistem kekebalan bayi dan mencegah perdarahan.

"Bayi lahir langsung dilakukan IMD selama satu jam..."

(Bidan Ruang Bersalin, 33th)

"Menurut jurnal-jurnal Internasional itu memang bagus dilakukan karena ada manfaat dari colostrum, terus secara psikologis dan cara kehangatan bayi ada manfaat untuk bayi. Karena kan..risiko bayi begitu lahir kan hipotermi. Nah diharapkan dengan skin to skin itu bisa mendapatkan kehangatan sama dengan suhu tubuh ibunya itu..."

(dr. SpOG, 35th)

Informan mendapatkan informasi mengenai IMD berasal dari hasil sharing rapat bulanan di ruang bersalin dan internet.

“..kita kan sering ada rapat bulanan yah disini. Jadi sharing juga dari temen - temen yang udah dapet ilmunya. Terus apa yah..sosmed. ada juga tuh parenting..yaa kebanyakan searching."

(Bidan Ruang Bersalin, 33th)

\section{Pengetahuan Ibu postpartum tentang IMD}

Pengetahuan informan ibu mengenai IMD dari delapan informan ibu lima di antaranya belum mengetahui istilah dan manfaat IMD. Sementara tiga di antaranya mengatakan bahwa IMD bermanfaat untuk memberikan kehangatan, menyatukan dirinya dengan sang bayi. Informasi IMD didapatkan dari tetangga dan informasi dari HP suami.

"Engga..emang apa itu IMD?"

(Informan Ibu, 32th, persalinan vakum, IMD)

"Kalo info dari tetangga-tetangga si katanya biar nyatu sama ibunya. Ada yang bilang gitu. Ada juga yang bilang biar deket sama ibunya..."

(Informan Ibu, 22th, persalinan normal, IMD)

Selama melakukan pemeriksaan kehamilan salah satu informan mengatakan bahwa tenaga kesehatan di pelayanan kesehatan pertama menganjurkan dirinya untuk membaca buku KIA, tetapi belum memberikan informasi mengenai IMD secara langsung.

"Lupa si, Cuma baca sekali kali aja. Cuma tau dari itu aja gatau dari mana-mana lagi. Dari posyandu disuru baca-baca. Kalo pas di posyandu paling diteranginnya tentang apa tuh..tentang kelainan iniii..sebelum persalinan, kelainan sebelum persalinan ini..ini... apa aja. Gituu..."

(Informan ibu 30th, melahirkan normal, IMD)

Seluruh pasien yang menjadi informan ibu merupakan pasien rujukan dari fasilitas pelayanan kesehatan pertama. Jika dihubungkan dengan pelaksanaan IMD, rumah sakit berusaha sebaik mungkin agar IMD dapat terlaksana. Namun ketika terdapat informan ibu belum terpapar informasi IMD, hal ini berisiko terjadi pasien yang enggan untuk dilakukan IMD.

“...Kita rumah sakit hanya menerima yaa.. mungkin promosi dan preventif di jenjang PPK satunya kurang."

\section{(Manajemen RS, 51th)}

"Kalo itu yaa teteplah dijelasin lagi, pentingnya $I M D$, fungsinya apa segala macem sampe dia mau. Setelah kita jelasin masa ibu ga kasiann..akhirnya setelah kita edukasi lagi akhirnya mau."

(Bidan Ruang Bersalin, 26th)

\section{Dukungan RS terhadap IMD}

\section{Edukasi Tenaga Kesehatan RS tentang IMD}

Edukasi IMD dari tenaga kesehatan merupakan salah satu bentuk bahwa rumah sakit mendukung adanya pelaksanaan IMD. Namun, sebagian besar edukasi dari tenaga kesehatan diberikan ketika pasien datang sudah dalam keadaan untuk bersalin. Sehingga edukasi yang diberikan tenaga kesehatan di rumah sakit dirasakan kurang optimal. 
"Pas lahiran..soalnya kalo pas lagi mules mules.. itu ga masuk. He eh..kalo pun sebelum tergantung sikonnya. Kalo masi fase laten..masi bisa ngomong. Masi bisa diajak komunikasi baik. Diselipkan yaa sebagian. Edukasi yang itu tu..yang tanda tangan itu. Tapi kalo masuknya udah fase aktif. Kan kita gatau yahh. Pasien datengnya pas fase laten apa fase aktif. Biasanya pas bayi lahir si. Soalnya kalo pas fase aktif udah gabisa diajak ngomong."

(Bidan Ruang Bersalin, 33th)

\section{Sarana dan Prasarana RS yang Mendukung} IMD

Berdasarkan hasil observasi terdapat beberapa poster yang menunjukkan bahwa rumah sakit mendukung keberhasilan pasien ibu untuk menyusui dan pelaksanaan IMD yang ditunjukkan pada Gambar 1.

Gambar 2 menunjukkan sarana dan prasarana yang dimaksud disini adalah kelengkapan fasilitas yang disediakan oleh manajemen RSUD Kota Cilegon untuk menunjang pelaksanaan program IMD. Bentuk fasilitas tersebut terdiri dari poster, mengingat tidak begitu banyak perlengkapan yang diperlukan dalam melaksanakan IMD di rumah sakit. Untuk melaksanakan IMD, cukup dengan menggunakan selimut yang pasien bawa untuk menghangatkan bayi.

"Ada..ada poster yang ditempel itukan. Dukungan menyusui. Itu ada posternya.

(Bidan Ruang Bersalin, 33th)

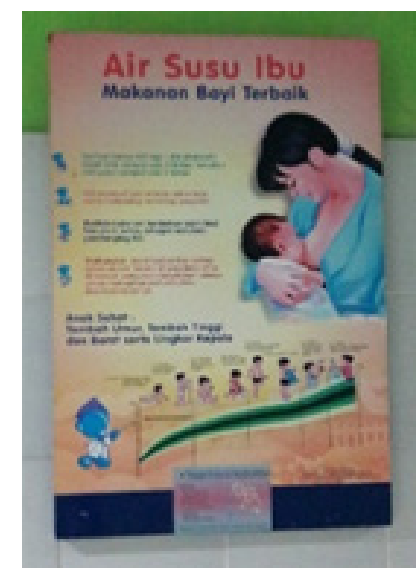

Gambar 1. Mengenai Air Susu Ibu merupakan makanan terbaik untuk bayi

*Sumber: Dokumentasi dari Ruang Bersalin

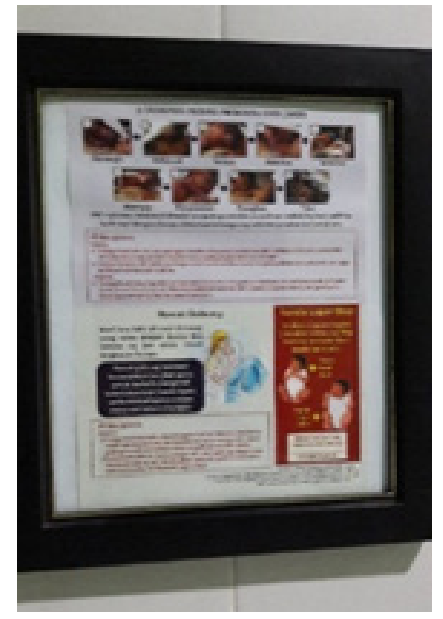

\section{Gambar 2. Mengenai Sembilan Tahapan IMD}

*Sumber: Dokumentasi dari Ruang Bersalin

"Kalo misalkan IMD mah ga terlalu banyak yah. Kan fokus ke edukasi yaa..kan Cuma begitu aja kan. Di templokin gitu aja kan ke dada ibunya. Satu jam ke dada ibunya."

\section{(Bidan Ruang Bersalin, 28th)}

\section{Pembahasan}

\section{Pelaksanaan IMD}

Inisiasi menyusu dini, yang disingkat dengan IMD, merupakan program yang sedang dianjurkan pemerintah. Menyusu dan bukan menyusui merupakan gambaran bahwa IMD bukan program ibu menyusui bayi tetapi bayi yang harus aktif menemukan sendiri puting susu ibu. Program ini dilakukan dengan cara langsung meletakkan bayi baru lahir di dada ibunya dan membiarkan bayi ini merayap untuk menemukan puting susu ibu. Untuk menyusui, IMD harus dilakukan langsung saat lahir, tanpa boleh ditunda dengan kegiatan menimbang atau mengukur bayi. Proses ini berlangsung harus skin to skin antara ibu dan bayi. ${ }^{9}$

IMD di RSUD Kota Cilegon belum optimal pada berbagai jenis metode persalinan. Pelaksanaan IMD hanya dilakukan pada jenis persalinan pervaginam, namun sudah terlaksana cukup baik di ruang bersalin. Dari hasil observasi pada persalinan pervaginam, bayi dilakukan IMD selama satu jam enam menit. Selama bayi dilakukan IMD bayi melakukan aktivitas untuk mencari puting. Pada saat dilakukan IMD sempat dilakukan jeda waktu untuk dilakukan pemotongan tali pusat, kemudian proses IMD dilanjutkan. 
Pelaksanaan IMD yang dirasakan oleh informan ibu mengatakan bahwa dirinya mendapatkan kehangatan ketika bayi berada diatas dadanya, selain itu bayi menjadi lebih tenang dan tidak banyak menangis. Kontak kulit antara ibu dan bayi banyak memberikan manfaat termasuk dalam proses menyusui. Dalam sebuah studi yang menyimpulkan bahwa kontak kulit bisa dengan cepat meningkatkan perasaan positif ibu dan memperpendek waktu jika ibu menemui kesulitan pelekatan saat bayi baru lahirnya hendak menyusu. ${ }^{10}$

\section{Prosedur Operasional Baku IMD}

Prosedur operasional baku (POB) adalah pedoman atau acuan untuk melaksanakan tugas pekerjaan sesuai dengan fungsi dan alat penilaian kinerja instansi pemerintah berdasarkan indikator teknis, administrasif dan prosedural sesuai dengan tata kerja, prosedur kerja dan sistem kerja pada unit kerja yang bersangkutan. ${ }^{11}$ Sebagai suatu instrumen manajemen, POB berlandaskan pada sistem manajemen kualitas (Quality Management System), yakni sekumpulan prosedur terdokumentasi dan praktek-praktek standar untuk manajemen sistem yang bertujuan menjamin kesesuaian dari suatu proses dan produk (barang dan/atau jasa) terhadap kebutuhan atau persyaratan tertentu. ${ }^{11}$

POB IMD di RSUD Kota Cilegon sudah ada, hanya saja POB tersebut hanya berlaku untuk persalinan pervaginam. Sementara sebab POB pelaksanaan IMD hanya berlaku pada proses persalinan pervaginam saja, hal ini dikarenakan sebagian kasus persalinan dengan kegawatdaruratan yang tidak memungkinkan untuk dilakukan IMD dan adanya kendala pada sumber daya manusia yang belum bisa dipenuhi. Salah satunya adalah kehadiran dokter anak di ruang operasi dan keterlibatan dari tenaga kesehatan lainnya seperti persetujuan dokter operator dan anestesi. Hal ini menjadi tantangan tersendiri bagi manajemen rumah sakit untuk bisa melaksanakan secara maksimal karena harus melibatkan banyak pihak.

Berdasarkan telaah dokumen SOP IMD terakhir dibuat pada tahun 2016 dan belum dilakukan revisi. Memperbaharui prosedur yang sudah usang merupakan tugas manajemen dalam menghadapi tantangan-tantangan baru dalam suatu organisasi/ program sehingga perlu dilakukan evaluasi terhadap prosedur berlaku secara berkala. ${ }^{12}$

\section{Pelatihan Tenaga Kesehatan}

Sebagian informan yang dilakukan wawancara mengatakan belum pernah mengikuti pelatihan khususnya yang berkaitan dengan IMD. Sumber daya utama dalam suatu organisasi untuk mencapai tujuannya adalah manusia yang memiliki bakat, kreativitas dan kemampuan. Peningkatan kemampuan tenaga kesehatan bisa dilakukan dengan cara memberikan pelatihan. Pelatihan adalah sebuah proses mengajarkan pengetahuan dan keahlian tertentu serta sikap agar karyawan semakin terampil dan mampu dalam melaksanakan tanggung jawabnya dengan semakin baik sesuai dengan standar. ${ }^{13}$

Salah satu penyebab kurangnya pelatihan pada sebagian besar tenaga kesehatan di RSUD Kota Cilegon adalah adanya kendala pada anggaran rumah sakit. Bagian perencaaan dan diklat rumah sakit harus menyeleksi pelatihan apa saja yang menjadi prioritas dan dibutuhkan rumah sakit pada waktu tersebut. Banyaknya pengajuan yang masuk ke bagian diklat dan perencanaan menjadikan belum bisa dipenuhinya kebutuhan pelatihan untuk tenaga kesehatan secara maksimal.

\section{Pengetahuan Tenaga Kesehatan dan ibu postpartum tentang IMD}

Berdasarkan hasil wawancara mendalam didapatkan bahwa pengetahuan tenaga kesehatan cukup baik tentang IMD. Sebagian besar tenaga kesehatan mampu menjelaskan pengertian, manfaat dan prosedur IMD yang benar. Pengetahuan tenaga kesehatan yang cukup baik mampu meningkatkan pemberian pelayanan kesehatan, seperti dalam penelitian yang menjelaskan bahwa pengetahuan, sikap dan perilaku dokter yang secara aktif terlibat dalam promosi menyusui dapat memberikan efek pada ibu untuk menyusui. Ibu percaya bahwa dokter merupakan sumber informasi terpercaya mengenai pemberian ASI. ${ }^{14}$

Pengetahuan adalah gejala yang ditemui dan diperoleh manusia melalui pengamatan inderawi. Pengetahuan muncul ketika seseorang menggunakan indera atau akal budidaya untuk mengenali benda atau kejadian tertentu yang belum pernah dilihat atau dirasakan sebelumnya ${ }^{15}$ ataupun rasa malu 
untuk meminta dokter yang membantu persalinan untuk melakukannya. ${ }^{2}$ Kurangnya pengetahuan dari pasien maupun keengganan untuk melakukan IMD berisiko bisa ditemukan. Sebagian orang tua ada yang merasa risih dan tidak percaya seorang bayi yang baru lahir dapat mencari sendiri susu ibunya.

Peran dan dukungan petugas kesehatan dengan memberikan informasi seputar menyusui merupakan salah satu faktor penunjang terlaksananya IMD, maka perlu dilakukan upaya untuk meningkatkan pemahaman ibu tentang pentingnya IMD melalui penyuluhan dan konseling seperti pada saat melakukan kunjungan pemeriksaan kehamilan. Begitu pula dalam perilaku ibu yang memberikan ASI eksklusif kepada bayinya, jika mempunyai pengetahuan yang baik tentang ASI dari informasi petugas kesehatan mungkin kecenderungan untuk tidak mau dilakukan IMD bisa lebih rendah.

\section{Dukungan Rumah Sakit terhadap IMD Edukasi Tenaga Kesehatan tentang IMD}

IMD yang dilanjutkan dengan pemberian ASI Eksklusif merupakan salah satu upaya untuk meningkatkan kesehatan bayi dan balita. Informasi mengenai proses IMD sangat berpengaruh besar pada pembentukan niat ibu yang akan segera melahirkan untuk mau menerapkan proses IMD pasca melahirkan. Peraturan Pemerintah No.33 Tahun 2012 tentang pemberian ASI eksklusif yang telah mengatur mengenai pelaksanaan IMD, pada pasal 9 telah menjelaskan bahwa tenaga kesehatan dan penyelenggara fasilitas pelayanan kesehatan wajib melakukan proses IMD pada setiap ibu segera setelah proses melahirkan, memberikan informasi dan edukasi mengenai pentingnya IMD kepada ibu dan keluarganya semenjak pemeriksaan kehamilan sampai dengan mendekati proses persalinan. ${ }^{5}$ Namun, hal yang dialami RSUD Kota Cilegon adalah sebagian besar pasien yang datang merupakan pasien rujukan yang masi belum terpapar pentingnya informasi mengenai IMD. Sehingga pemberian edukasi dari tenaga kesehatan mengenai IMD menjadi tidak optimal.

\section{Sarana dan Prasarana}

Keberhasilan suatu kegiatan sangat dipengaruhi banyak hal salah satunya adalah tersedianya sarana dan prasarana yang memadai untuk menunjang pelaksanaan kegiatan tersebut. Ketersediaan fasilitas merupakan salah satu faktor yang mempengaruhi kepatuhan dan termasuk faktor pemungkin. ${ }^{16}$ Fasilitas pendukung untuk pelaksanaan IMD dirasakan tidak begitu banyak dibutuhkan. Tenaga kesehatan cukup dengan meminta selimut bayi ketika akan melaksanakan skin to skin bayi kepada dada ibunya.

Sumber Informasi mengenai pentingnya IMD dapat diperoleh dari berbagai media, antara lain poster, banner, leaflet dan bahkan dari petugas kesehatan. Sementara di rumah sakit dibutuhkan media promosi kesehatan yang baik untuk mengajak pasien mau dilakukannya IMD di rumah sakit. Salah satu media promosi kesehatan yang sudah diberikan rumah sakit adalah adanya poster yang sudah sesuai peletakannya, yakni di ruangan bersalin, sedangkan media leaflet untuk pasien belum mencukupi dan diusahakan dengan memberikan pengajuan ke bagian umum.

\section{Kesimpulan}

Pelaksanaan IMD di RSUD Kota Cilegon belum terlaksana optimal disebabkan belum terlaksana pada berbagai jenis metode persalinan dan pemenuhan rumah sakit yang belum optimal dalam pelatihan tenaga kesehatan.

\section{Ucapan Terima Kasih}

Penulis mengucapkan terimakasih kepada Orang tua, Suami, Kepala Badan Litbangkes dan para informan penelitian yang telah berpartisipasi dalam penelitian ini serta keluarga atas support \& bantuannya sehingga penelitian ini dapat berjalan dengan baik.

\section{Daftar Rujukan}

1. Patal \& Gedam. Effect Back Massage on Lactation among Postnatal Mothers. India. 2013.

2. Roesli, U. Inisiasi Menyusu Dini Plus ASI Eksklusif. Jakarta: Pustaka Bunda. 2008.

3. Baby Friendly Hospital Initiative. Revised Updated and Expanded For Integrated Care. Section 4 Hospital Self Appraisal and Monitoring. UNICEF and World Helath Organization. 2009.

4. Roesli, Utami., Panduan Inisiasi Menyusu Dini 
Plus ASI Eksklusif. Jakarta: 2012.

5. Peraturan Pemerintah (PP) nomor 33 tahun 2012 tentang Pemberian ASI Eksklusif, pasal 9 ayat 1

6. Donabedian, A. Exploration in Quality Assesment and Monitoring Volume 1. The Definition of Quality and Appropriates to Assesment. Health Administrarion Press, An Arbor. Michigan. 1980

7. Bergstorm, A., Okong, P., \& Ransjo-Arvidson, A. Immediate Maternal Thermal Responese To Skin To Skin Care Of Newborn. Acta paediatr, 96(5), 655-658. 2007.

8. Unicef. Breast crawl; Initiation of Breastfeeding by Breast Crawl, Breast Crawl.org. 2007.

9. JNPK-KR..Pelatihan Asuhan Persalinan Normal dan Lampiran Inisiasi Menyusu Dini. Jakarta : JNPK-KR. 2007.

10. Svensson, Kristin E., Marianne I Velandia, AnnSofi TMatthiesen, Barbara LWelles-Nystrom and Ann-marie E Widstrom, effects of mother-infant skin-to-skin contact on severe latch-on problems in older infants: a randomized trial. 2013. http://www.internationalbreastfeedingjournal. com/ content $/ 8 / 1 / 1$

11. Atmoko, T. Standar Operasional Prosedural (SOP) dan Akuntabilitas Kinerja Instansi Pemerintah, (7). 2004.

12. Terry, G. Prinsip-Prinsip Manajemen. 2013.

13. Mangkuprawira, Sjafri. Manajemen Sumber Daya Manusia Strategik. Jakarta: Ghalia Indonesia. 2002.

14. Arthur, C. R., Saenz, R.B., \& Replogle, W.H. Personal Breast-Feeding Behaviours of Female Physicians In Mississippi. Sputh Med j., 96(2), 130-135. 2003.

15. Meliono, I, dkk,. Pengetahuan dalam Kesehatan. Jakarta: Rineka Cipta. 2007.

16. Green Lawrence W. health Promotion Planning An Educational and Environtmental Approach. Mayfield Publishing Company. London: Mountain View-Toronto. 2011. 